\title{
Preparation of 2,2-dimethylchroman-4-ones from 5-alkyl-substituted resorcinols: microwave-assisted synthesis and theoretical calculations
}

\author{
Paula Morales, Luis Miguel Azofra, José Cumella, Laura Hernandez-Folgado, \\ María Roldán, Ibon Alkorta, and Nadine Jagerovic* \\ Instituto de Química Médica, Consejo Superior de Investigaciones Científicas, \\ Calle Juan de la Cierva, 3, E-28006 Madrid, Spain \\ E-mail: nadine@iqm.csic.es
}

Dedicated to Professor Rosa María Claramunt Vallespí on the occasion of her $65^{\text {th }}$ birthday

\begin{abstract}
The influence of different 5-alkyl-substituted resorcinols on the formation of 2,2-dimethylchroman-4-ones is examined experimentally and theoretically. Structures are fully assigned by means of experimental and theoretical ${ }^{13} \mathrm{C}$ and ${ }^{1} \mathrm{H}$ NMR chemical shifts. Based on experimental and theoretical calculations of Friedel-Crafts acylation, it is possible to explain the formation of 2,2-dimethyl-5-hydroxychroman-4-ones and/or 2,2-dimethyl-7-hydroxychroman-4-ones. Evaluation of their biological activity as cannabinoid receptor ligands is also reported.
\end{abstract}

Keywords: Chromanone, DFT calculation, Friedel-Crafts reactions, cannabinoids

\section{Introduction}

Chroman-4-ones are attractive compounds not only because of their therapeutic applications but also as intermediates in preparation of more complex structures. As reported by Saengchantara and Wallace ${ }^{1}$ in a review covering chromanols, chromanones and chromones, many chroman-4ones are isolated from natural sources such as Dysophylla stellata, rhizomes of rhubarb, or Penicillium frequentans. Examples of these compounds include cannabichromanones identified as components of the Cannabis sativa plant. ${ }^{2,3}$ Moreover, 2,2-dimethyl-5-hydroxychroman-4ones have been described as intermediates in the synthesis of tetrahydrocannabinols ${ }^{4}$ and, as we have reported, in the synthesis of cannabinoid chromenopyrazoles. ${ }^{5}$ A survey of the preparations of differently substituted 2,2-dimethylchroman-4-ones was published by Tímár et al. ${ }^{6}$ twelve years ago. Most of them are prepared by reacting the appropriate phenol with 3,3-dimethylacryloyl chloride or its corresponding acid in presence of Lewis acid. However, it has been 
mentioned in the literature that the reactions are not always successful, providing poor yields or mixtures of different chromanones, or requiring long reaction times. ${ }^{7,8}$ On consideration of this, a study was undertaken to examine the influence of different 5-alkyl-substituted resorcinols on the formation of 2,2-dimethychroman-4-ones using both microwave (MW) assisted reactions and conventional heating (C.H.). Structures have been fully assigned by means of experimental and theoretical ${ }^{13} \mathrm{C}$ and ${ }^{1} \mathrm{H}$ NMR chemical shifts. Finally, the first step, Friedel-Crafts acylation reaction has been examined theoretically in order to correlate the experimental evidence using Density Functional Theory (DFT).

\section{Results and Discussion}

2,2-Dimethyl-5-hydroxychroman-4-ones (2) and 2,2-dimethyl-7-hydroxychroman-4-ones (3) were prepared from various resorcinols as indicated in Scheme 1. Resorcinol (1a), orcinol (1b) and olivetol (1d) are commercially available. The starting resorcinol 1c was prepared starting from 1-bromo-3,5-dimethoxybenzene. Sonogashira coupling ${ }^{9}$ of the starting material gave 5-(1butynyl)-1,3-dimethoxybenzene in good yield (Scheme 2). Then, 5-butyl-1,3-dimethoxybenzene was obtained in quantitative yield by hydrogenation using $\mathrm{Pd} / \mathrm{C}$ as catalyst. Demethylation with boron tribromide finally provided the desired resorcinol 1c in acceptable yield. Resorcinol 1e bearing a dimethylheptyl substituent was prepared from the corresponding dimethoxy derivative.

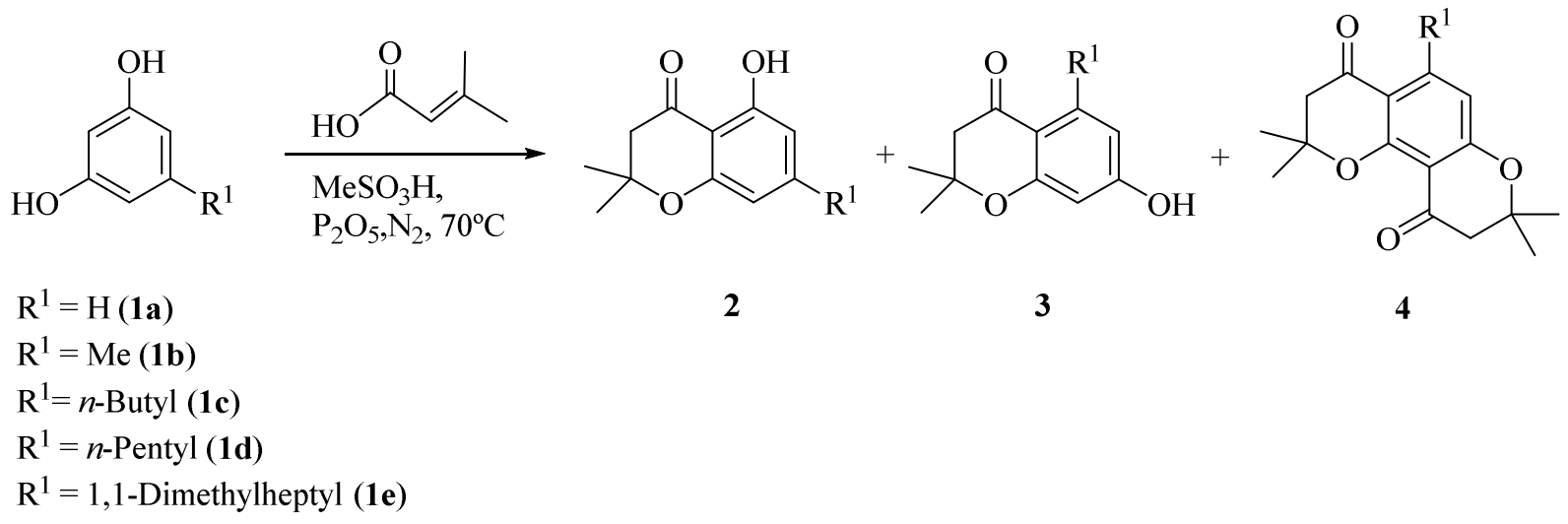

Scheme 1. Reaction of resorcinols with 3,3-dimethylacrylic acid.<smiles>CCC#Cc1cc(OC)cc(OC)c1</smiles>

Scheme 2. Preparation of 5-n-butyl-1,3-dihydroxybenzene (1c). 
Upon treatment of resorcinols (1a-1e) with 3,3-dimethylacrylic acid in methanesulfonic acid in presence of phosphorus pentoxide, the Friedel-Crafts acylation was expected to take place at either the 2 or 6 position of 1,3-dihydroxybenzene (Scheme 1). To study the effect of the alkyl substituents on the resorcinol, reaction parameters (solvent, molar ratio of reactants, catalyst, and temperature) were at first investigated. The reactions were carried out under the most advantageous reactant ratio: resorcinol / phosphorus pentoxide / 3,3-dimethylacrylic acid [1/1.21.5/1.5-2] using methanesulfonic acid as solvent at $70^{\circ} \mathrm{C}$. Under these conditions the reaction was performed under microwave irradiation for 10,20 or 60 minutes or with conventional heating for 12 hours. The reactions were monitored by HPLC/MS (C-18 reverse phase column, eluent: $\mathrm{MeCN} / \mathrm{H}_{2} \mathrm{O}$ ) that allowed the ratio in which regioisomers $\mathbf{2}$ and $\mathbf{3}$ were formed to be determined.

As reported in Table 1, 2,2-dimethyl-7-hydroxychroman-4-one was isolated as the only regioisomer in the case of $\mathbf{3 a}$ and $\mathbf{3 b}\left(\mathrm{R}^{1}=\mathrm{H}\right.$ and $\left.\mathrm{R}^{1}=\mathrm{Me}\right)$, whereas the regioisomer 2,2dimethyl-5-hydroxychroman-4-one was isolated as the unique isomer for $\mathbf{2 e}\left(\mathrm{R}^{1}=1,1\right.$ dimethylheptyl). The reaction of 3,3-dimethylacrylic acid with 5-butyl-1,3-dihydroxybenzene $\left(\mathrm{R}^{1}=n\right.$-butyl) and olivetol $\left(\mathrm{R}^{1}=n\right.$-pentyl) resulted in the formation of both isomers $\mathbf{2}(\mathbf{2 c}, \mathbf{2 d})$ and $\mathbf{3}(\mathbf{3 c}, \mathbf{3 d})$. The ratio in the crude product mixture could be easily determined by HPLC/MS. These ratios are reported in Table 1. Regioisomers $\mathbf{2}$ and $\mathbf{3}$ could be isolated by column chromatography. Two-dimensional NMR experiments were of particular value for the identification of the regioisomers $\mathbf{2}$ and 3, as shown in Figure 1. Moreover, the chemical shifts of

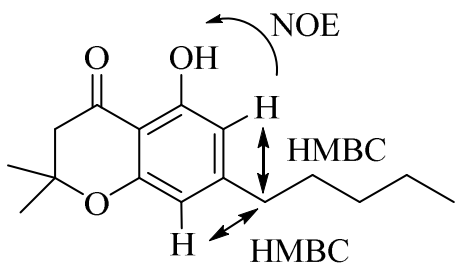

2d

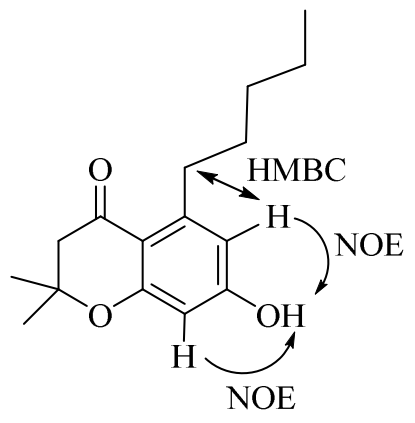

3d

Figure 1. Specific assignments of regioisomers 2 and $\mathbf{3}$ were based on ${ }^{13} \mathrm{C}-{ }^{1} \mathrm{H}$ Heteronuclear Multiple-Bond Correlation (HMBC) and Nuclear Overhauser Enhancement (NOE) spectroscopy.

All the molecules $\mathbf{2}$ and $\mathbf{3}$ obtained experimentally have also been calculated using GIAODFT methods at B3LYP/6-311++G(d,p) computational level. The ${ }^{13} \mathrm{C}-\mathrm{NMR}$ theoretical data nicely resemble the experimental ones, showing an excellent linear correlation with the experimental findings $\left(\mathrm{R}^{2}=0.993\right)$ and an absolute average error of $3.1 \mathrm{ppm}$. The ${ }^{1} \mathrm{H}-\mathrm{NMR}$ theoretical results show an absolute average error of $0.18 \mathrm{ppm}$ and a $\mathrm{R}^{2}$ value of 0.99 . 
Table 1. Reaction of 5-alkyl-substituted resorcinols with 3,3-dimethylacrylic acid in methanesulfonic acid under given heating conditions and the ratios of the two isomers and the diacylated product determined by HPLC/MS areas analysis

\begin{tabular}{|c|c|c|c|c|c|}
\hline Entry & $\mathrm{R}^{1}$ & Heating condition $^{a}$ & 2 & 3 & 4 \\
\hline 1 & \multirow{4}{*}{$\mathrm{H}$} & $10 \min \mathrm{MW}$ & - & $100 \%(3 \mathbf{a})$ & - \\
\hline 2 & & $20 \mathrm{~min} \mathrm{MW}$ & - & $100 \%(\mathbf{3 a})$ & - \\
\hline 3 & & 1h MW & - & $87 \%(\mathbf{3 a})$ & $13 \%(\mathbf{4 a})$ \\
\hline 4 & & 12h C.H. & - & $100 \%(3 \mathbf{a})$ & - \\
\hline 5 & \multirow{4}{*}{$\mathrm{Me}$} & $10 \min \mathrm{MW}$ & - & $100 \%(3 \mathbf{b})$ & - \\
\hline 6 & & $20 \min \mathrm{MW}$ & - & $100 \%(3 \mathbf{b})$ & - \\
\hline 7 & & 1h MW & - & $94 \%(3 \mathbf{b})$ & $6 \%(4 b)$ \\
\hline 8 & & 12h C.H. & - & $100 \%(3 \mathbf{b})$ & - \\
\hline 9 & & $10 \min \mathrm{MW}$ & $22 \%(\mathbf{2 c})$ & $78 \%(\mathbf{3 c})$ & - \\
\hline 10 & & $20 \min \mathrm{MW}$ & $20 \%(\mathbf{2 c})$ & $80 \%(\mathbf{3 c})$ & - \\
\hline 11 & & 1h MW & $13 \%(\mathbf{2 c})$ & $70 \%(\mathbf{3 c})$ & $17 \%(\mathbf{4 c})$ \\
\hline 12 & & 12h C.H. & $24 \%(\mathbf{2 c})$ & $76 \%(\mathbf{3 c})$ & - \\
\hline 13 & & $10 \min \mathrm{MW}$ & $41 \%(\mathbf{2 d})$ & $59 \%(\mathbf{3 d})$ & - \\
\hline 14 & & $20 \min \mathrm{MW}$ & $26 \%(\mathbf{2 d})$ & $50 \%(3 d)$ & $24 \%(\mathbf{4 d})$ \\
\hline 15 & & 1h MW & $17 \%(\mathbf{2 d})$ & $39 \%(\mathbf{3 d})$ & $44 \%(\mathbf{4 d})$ \\
\hline 16 & & 12h C.H. & $25 \%(\mathbf{2 d})$ & $75 \%(3 d)$ & - \\
\hline 17 & & $10 \min \mathrm{MW}$ & $100 \%(\mathbf{2 e})$ & & - \\
\hline 18 & & $20 \min \mathrm{MW}$ & $100 \%(\mathbf{2 e})$ & & - \\
\hline 19 & & 1h MW & $100 \%(\mathbf{2 e})$ & & \\
\hline 20 & & 12h C.H. & $100 \%(\mathbf{2 e})$ & & - \\
\hline
\end{tabular}

${ }^{a} \mathrm{MW}$ : microwave irradiation; C.H.: conventional heating

Altering the reaction conditions did not significantly affect the regiochemical outcome. However, by increasing the microwave exposure to 1 hour, diacylated product (4) was detected in the reaction mixture except for 1,1-dimethylheptyl derivative that was not observed (Table 1 entry 19). These compounds (4a, $\mathbf{4 b}, \mathbf{4 c}$ and $\mathbf{4 d}$ ) were identified by HPLC/MS that also allowed the determination of the ratios in the crude reaction. The structures of $\mathbf{4 a}$ and $\mathbf{4 d}$, which were isolated by chromatography, were unambiguously determined by MS and NMR experiments. 
Note that the diacylated product 4 could be formed from both 2,2-dimethyl-5-hydroxychroman4-one (2c, 2d) and 2,2-dimethyl-7-hydroxychroman-4-one (3c, 3d).

It is interesting to note the difference of reactivity between the microwave-assisted reactions and the reaction carried out by conventional heating. Compounds $\mathbf{3 a}, \mathbf{3 b}$ and $\mathbf{3 d}$ (10 min) formed faster than $\mathbf{4 a}, \mathbf{4 b}$ and $\mathbf{4 d}(1 \mathrm{~h})$ are the kinetic products of this reaction. Compounds $\mathbf{4 a}, \mathbf{4 b}$ and $\mathbf{4 d}$ obtained in lower amount are thermodynamically more stable than the corresponding compounds 3. Under conventional heating conditions, the reaction seems to be fully kinetically controlled since there is no formation of $\mathbf{4}$.

In an attempt to explain the reactivity of different resorcinols with 3,3-dimethylacrylic acid, theoretical calculations have been performed. Thus, the reactivity of three systems has been considered (Scheme 3); resorcinol, orcinol and 5-tert-butyl-1,3-dihydroxybenzene have been selected. Hydrogen and methyl groups in $\mathrm{R}^{1}$ are the corresponding substituents of resorcinol and orcinol. The tert-butyl group in $\mathrm{R}^{1}$ was chosen to mimic the 1,1-dimethylheptyl moiety.

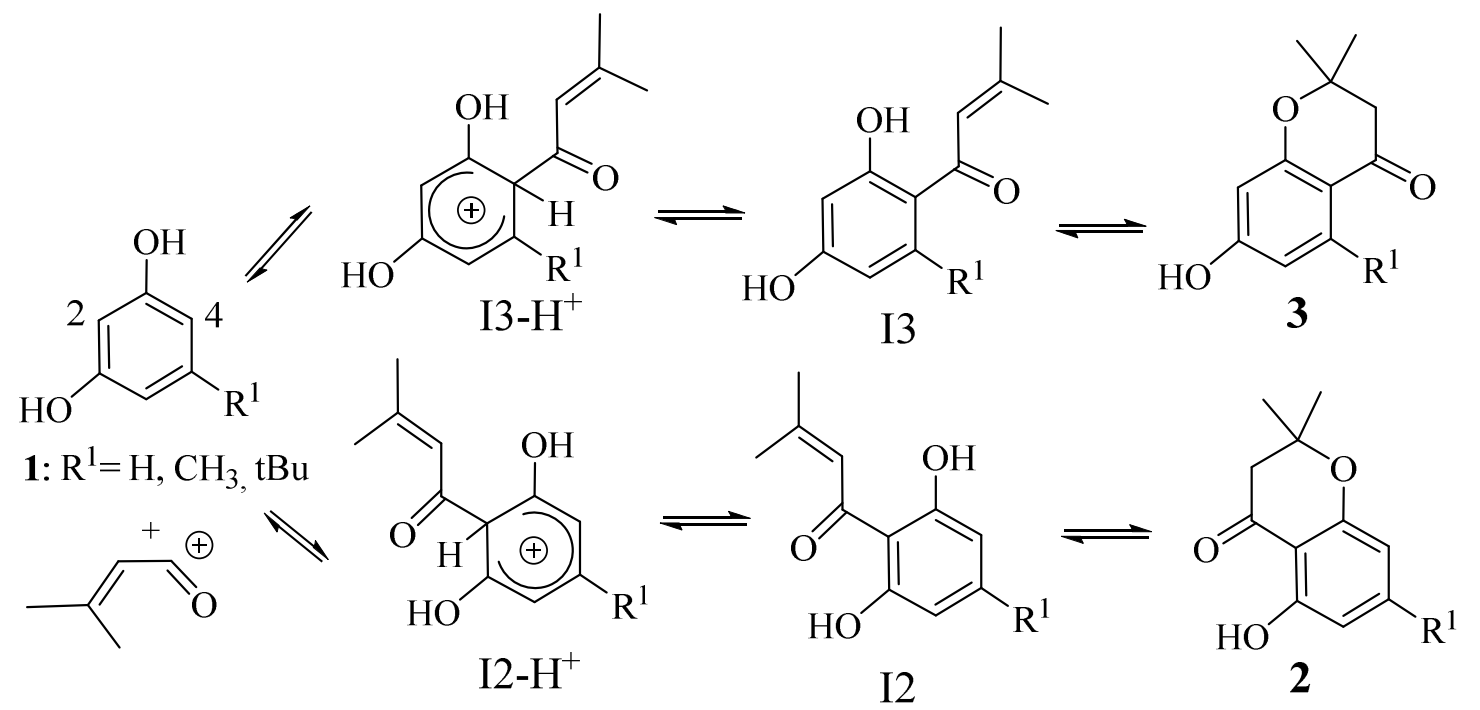

Scheme 3. Schematic representation of the reaction.

For each of the three starting molecules, two possibilities have been considered: the reaction on the $\mathrm{C} 2$ and the one in $\mathrm{C} 4$. Two possible transition state (TS) paths have been explored for the Friedel-Crafts acylation depending on the disposition of the attacking carbonyl molecule with respect to the aromatic ring (Figure 2). 


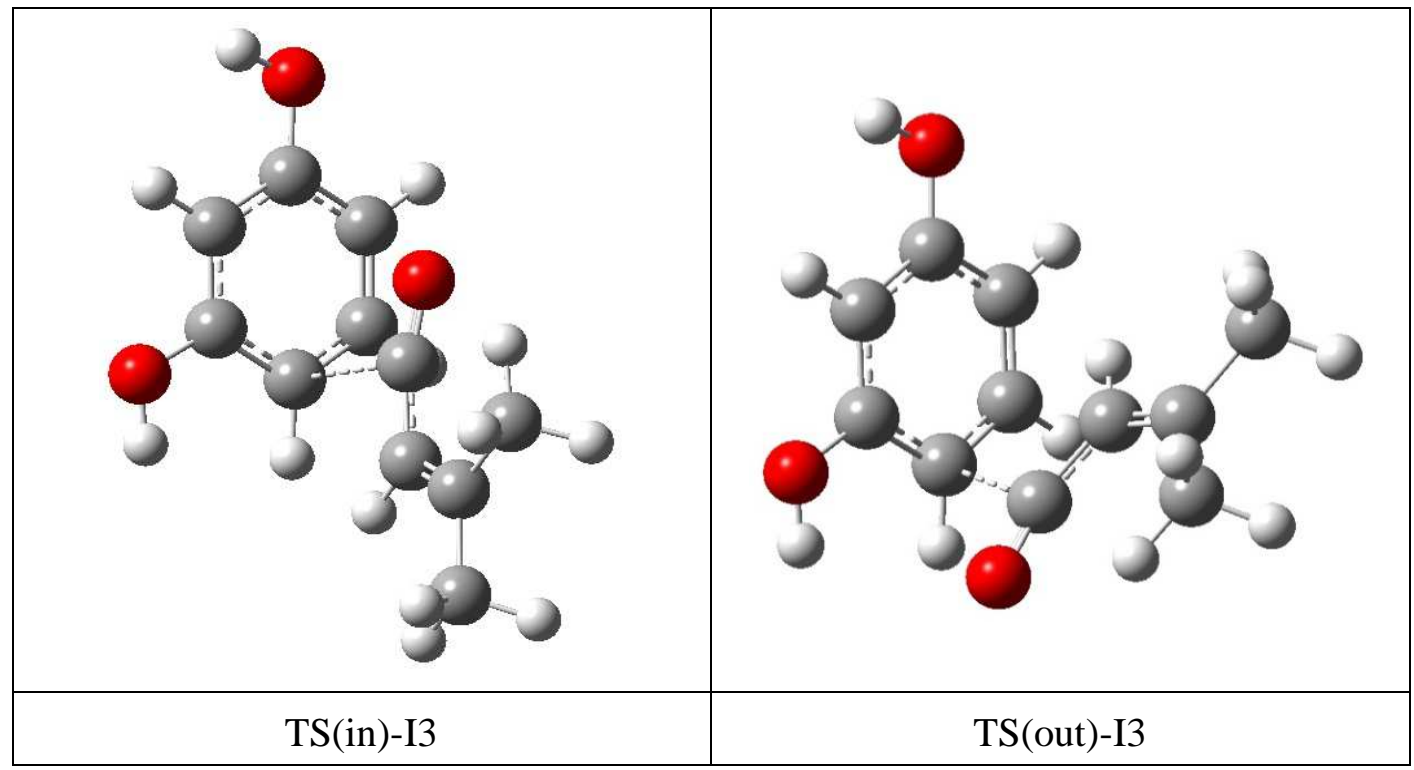

Figure 2. The two TS found for the Friedel-Crafts acylation that yield the formation of $\mathrm{I} 3-\mathrm{H}^{+}$, $\mathrm{R}^{1}=\mathrm{H}$.

Small values of the barriers are found with respect to the isolated reactants (Table 2). The differences between the most favorable TS that yields $\mathrm{I} 3-\mathrm{H}^{+}$and $\mathrm{I} 2-\mathrm{H}^{+}$are small being in all the cases the one that yields $\mathrm{I} 3-\mathrm{H}^{+}$the smaller. However, the relative energies of the charged species obtained in this first step of the reaction are different depending on the $\mathrm{R}^{1}$ group. Thus, for $\mathrm{R}^{1}=\mathrm{H}$ and $\mathrm{Me}$, the most stable molecule correspond to the $\mathrm{I} 3-\mathrm{H}^{+}$while for $\mathrm{R}^{1}=t$ - $\mathrm{Bu}$ it is $\mathrm{I} 2-\mathrm{H}^{+}$.

The relative energies of the neutral intermediate molecules I3 and I2, as well as the bicyclic structures $\mathbf{3}$ and $\mathbf{2}$ obtained after a subsequent intramolecular Michael addition are gathered in Table 3. Only in the case of $\mathrm{X}=\mathrm{H}$ is I3 more stable than I2. In the rest of the cases, I 2 is more stable than I3 and the same happened between 2 and 3. In addition, the energetic differences increase with the size of the $\mathrm{R}^{1}$ group.

Table 2. Relative energy $(\mathrm{kJ} / \mathrm{mol})$ of the TS and Friedel-Crafts acylation with respect to the isolated reactants. In parenthesis, the population based on the energies of $\mathrm{I} 3-\mathrm{H}^{+}$and $\mathrm{I} 2-\mathrm{H}^{+}$is indicated. Values at B3LYP/6-311++G(d,p) computational level in PCM, $\varepsilon=80$

\begin{tabular}{ccccccc}
\hline & TS(in)-I3 & TS(out)-I3 & TS(in)-I2 & TS(out)-I2 & I3-H $^{+}$ & I2-H $^{+}$ \\
\hline $\mathrm{H}$ & 0.4 & 2.3 & 6.1 & 4.2 & -49.9 & -32.9 \\
& & & & & $(99.9 \%)$ & $(0.1 \%)$ \\
$\mathrm{Me}$ & -3.9 & -0.1 & 0.6 & -0.9 & -53.8 & -47.8 \\
& & & & & $(92 \%)$ & $(8 \%)$ \\
$t$-Bu & -6.2 & -4.7 & -3.7 & -5.5 & -54.2 & -58.3 \\
& & & & & $(16 \%)$ & $(84 \%)$ \\
\hline
\end{tabular}


Table 3. Relative energies $(\mathrm{kJ} / \mathrm{mol})$ of the I3, I2, 3 and $\mathbf{2}$ molecules

\begin{tabular}{ccccc}
\hline $\mathrm{R}^{1}$ & $\mathrm{I} 3$ & $\mathrm{I} 2$ & $\mathbf{3}$ & 2 \\
\hline $\mathrm{H}$ & 0.0 & 18.8 & 0.0 & -21.0 \\
$\mathrm{Me}$ & 0.0 & -9.1 & 0.0 & -32.2 \\
$t-\mathrm{Bu}$ & 0.0 & -53.9 & 0.0 & -66.3 \\
\hline
\end{tabular}

Based on the experimental and the computational results shown here, the Friedel-Crafts acylation that yields the formation of $\mathrm{I} 3-\mathrm{H}^{+}$and $\mathrm{I} 2-\mathrm{H}^{+}$seems to be the one responsible of the percentage of final products obtained. Thus, the calculated relative energies of the $\mathrm{I} 3-\mathrm{H}^{+}$and $\mathrm{I} 2-$ $\mathrm{H}^{+}$intermediates are able to explain the experimental results. In other terms, the influence of different 5-alkyl-substituted resorcinols on the formation of 2,2-dimethychroman-4-ones does not depend on the energetic barrier of the first step involved in Friedel-Crafts acylation. But it is rather the difference of relative energies of the charged species at the transition state that depends on the nature of the alkyl substituent. Based on these theoretical considerations, it has been possible to explain the formation of 2,2-dimethyl-5-hydroxychroman-4-ones and/or 2,2dimethyl-7-hydroxychroman-4-ones obtained experimentally.

\section{Affinity towards cannabinoid receptors}

The affinity of chromanones $\mathbf{2 d - e , ~ 3 a - d , ~} \mathbf{4 a}$ and $\mathbf{4 d}$ at $\mathrm{CB}_{1}$ and $\mathrm{CB}_{2}$ cannabinoid receptors were evaluated using radiolabeled binding assays.

Table 4. Binding affinity of chromanones and the reference cannabinoid WIN55,212-2 for $\mathrm{CB}_{1}$ and $\mathrm{CB}_{2}$ cannabinoid receptors

\begin{tabular}{ccc}
\hline Compd & $\mathrm{CB}_{1} K_{\mathrm{i}}(\mu \mathrm{M})^{a}$ & $\mathrm{CB}_{2} K_{\mathrm{i}}(\mu \mathrm{M})^{a}$ \\
$\mathbf{2 d}$ & $>40$ & $3.44 \pm 0.27$ \\
$\mathbf{2 e}$ & $1.35 \pm 0.38$ & $2.54 \pm 0.06$ \\
$\mathbf{3 a}$ & $>40$ & $>40$ \\
$\mathbf{3 b}$ & $>40$ & $>40$ \\
$\mathbf{3 c}$ & $>40$ & $>40$ \\
$\mathbf{3 d}$ & $>40$ & $1.28 \pm 0.08$ \\
4a & $>40$ & $4.41 \pm 0.18$ \\
$\mathbf{4 d}$ & $>40$ & $3.37 \pm 0.19$ \\
WIN55,212-2 $^{b}$ & $0.045 \pm 0.009$ & $0.037 \pm 0.002$ \\
\hline
\end{tabular}

${ }^{a}$ Values obtained from competition curves using $\left[{ }^{3} \mathrm{H}\right] \mathrm{CP} 55,940$ as radioligand for $\mathrm{CB}_{1}$ and $\mathrm{CB}_{2}$ cannabinoid receptors and are expressed as mean SEM values of at least three experiments. 
WIN55,212-2: (R)-(+)-[2,3-dihydro-5-methyl-3-(4-morpholinylmethyl)pyrrolo[1,2,3-de]-1,4benzoxazin-6-yl]-1-napthalenylmethanone.

The affinity constant $K_{i}$ was determined measuring the ability of the compound to displace $\left[{ }^{3} \mathrm{H}\right]-\mathrm{CP} 55,940$ (2-[(1R,2R,5R)-5-hydroxy-2-(3-hydroxypropyl)cyclohexyl]-5-(2-methyloctan-2yl)phenol) from human $\mathrm{CB}_{1}$ and $\mathrm{CB}_{2}$ receptors transfected into HEK293 EBNA cells. ${ }^{5}$ Standard cannabinoid ligand WIN55,212-2 was also assessed for comparison with the new compounds. The tested compounds displayed much lower affinity than the reference cannabinoid ligand. Although these affinities are low, these data suggest some relation structure-activity. In the 2,2dimethyl-7-hydroxychroman-4-one series (3), the lipophilic methylenic chain is necessary for $\mathrm{CB}_{2}$ receptor binding (3d). However, this is not the case for the tricyclic scaffold (4) for which the moderate $\mathrm{CB}_{2}$ affinity was independent of the lipophilic nature of the alkyl chain (4a and 4d). 2,2-Dimethyl-5-hydroxychroman-4-one $2 d$ showed weak but selective affinity for the $\mathrm{CB}_{2}$ cannabinoid receptors whereas the dimethylheptyl derivative $2 \mathbf{e}$ binds weakly to both receptors.

\section{Conclusions}

The influence of different 5-alkyl-substituted resorcinols on the formation of 2,2dimethychroman-4-ones does not depend on the energetic barrier of the first step involved in Friedel-Crafts acylation. But it is rather the difference of relative energies of the charged species at the transition state that depends on the nature of the alkyl substituent. Based on these theoretical considerations, it has been possible to explain the formation of 2,2-dimethyl-5hydroxychroman-4-ones and/or 2,2-dimethyl-7-hydroxychroman-4-ones obtained experimentally. From an experimental point of view, the use of microwave radiation considerably reduced reaction times but it did not increase reaction yields. At longer microwave irradiation, diacetylated products started to form in the reaction mixture. With respect to their biological activity, some of the chromanones described here showed moderate but selective affinity for the $\mathrm{CB}_{2}$ cannabinoid receptor.

\section{Experimental Section}

\section{Chemistry}

General. All commercially available reagents and solvents were used as supplied without further purification. Microwave-assisted synthesis was carried out with a Biotage Initiator Microwave $(0-400 \mathrm{~W}$ at $2.45 \mathrm{GHz})$. Column chromatography was performed using silica gel 60 (230-400 mesh). The purity of final compounds was determined by HPLC-MS and elemental analyses. HPLC-MS analysis was performed on a Waters 2695 HPLC system equipped with a Photodiode Array 2996 coupled to Micromass ZQ 2000 mass spectrometer (ESI-MS), using a reverse-phase 
column SunFire $^{\mathrm{TM}}(\mathrm{C}-18,4.6$ x $50 \mathrm{~mm}, 3.5 \mu \mathrm{m})$ and 5 min gradient A) MeCN/0.08\% formic acid, B) $\mathrm{H}_{2} \mathrm{O} / 1 \%$ formic acid visualizing at $\lambda=254 \mathrm{~nm}$. Elemental analyses were performed using a LECO CHNS-932 apparatus. ${ }^{1} \mathrm{H}$ and ${ }^{13} \mathrm{C}$ NMR spectra were recorded on a Bruker 300 (300 and $75 \mathrm{MHz}$ respectively) at $25^{\circ} \mathrm{C}$ with $\mathrm{CDCl}_{3}$ as solvent and TMS as internal standard. Chemical shifts were expressed in ppm $(\delta)$ and coupling constants were reported in Hz. Melting points were determined in open capillary tubes with a MP70 Mettler Toledo apparatus. 5-(1,1Dimethylheptyl)-1,3-dihydroxybenzene (1e) was prepared as described previously by some of us. $^{5}$

5-(1-n-Butynyl)-1,3-dimethoxybenzene (6). To a solution of the commercially available 1bromo-3,5-dimethoxybenzene $(\mathbf{5})(1.0 \mathrm{~g}, 4.6 \mathrm{mmol})$ in $\mathrm{Et}_{3} \mathrm{~N}(12 \mathrm{~mL})$ was added $\mathrm{CuI}(0.05 \mathrm{~g}$, $0.27 \mathrm{mmol}), \mathrm{PPh}_{3}(0.36 \mathrm{~g}, 1.3 \mathrm{mmol})$, and $\mathrm{Pd}_{2}(\mathrm{dba})_{3}(6.12 \mathrm{~g}, 0.13 \mathrm{mmol})$. Butyne was bubbled for 6 minutes under $\mathrm{N}_{2}$ atmosphere. The reaction was stirred at $80{ }^{\circ} \mathrm{C}$ overnight. The mixture was cooled to room temperature. The reaction mixture was filtered and the filtrate was evaporated in vacuo. The crude residue was further purified by column chromatography $\left(\mathrm{CH}_{2} \mathrm{Cl}_{2} /\right.$ hexane, 1:3) to give the pure title compound as a red oil $(0.80 \mathrm{~g}, 91 \%) ;{ }^{1} \mathrm{H} \mathrm{NMR}\left(\mathrm{CDCl}_{3}\right): \delta 6.67-6.55(\mathrm{~m}, 2 \mathrm{H}$, 4-H and 6-H), 6.39 (m, 1H, 2-H), $3.83\left(\mathrm{~s}, 6 \mathrm{H}, \mathrm{OCH}_{3}\right), 2.40$ (q, J 7.6 Hz, 2H, 3'-H), 1.25 (t, J 7.8 $\left.\mathrm{Hz}, 3 \mathrm{H}, 4^{\prime}-\mathrm{H}\right) .{ }^{13} \mathrm{C} \mathrm{NMR}\left(\mathrm{CDCl}_{3}\right): \delta=160.4$ (1-C and 3-C), 125.3 (5-C), 109.8 (4-C or 6-C), 109.3 (4-C or 6-C), 101.1 (2-C), 91.3 (2'-C), 79.8 (1'-C), $55.3\left(\mathrm{OCH}_{3}\right), 13.8$ (3'-C), 13.0 (4'-C); HPLC-MS: [A, 15\% - 100\%], $\mathrm{t}_{\mathrm{R}}=5.72 \mathrm{~min},(100 \%)$; MS $\left(\mathrm{ES}^{+}, \mathrm{m} / \mathrm{z}\right) 191[\mathrm{M}+\mathrm{H}]^{+}$; Anal. calcd. for $\mathrm{C}_{12} \mathrm{H}_{14} \mathrm{O}_{2}$ (190.24): C, 75.76; H, 7.42. Found: C, 75.89; H, 7.23.

5-n-Butyl-1,3-dimethoxybenzene (7). A solution of 5-(1-n-butynyl)-1,3-dimethoxybenzene (6) $(0.74 \mathrm{~g}, 3.8 \mathrm{mmol}))$ in $\mathrm{CH}_{2} \mathrm{Cl}_{2}(15 \mathrm{~mL})$ was degassed and flushed with $\mathrm{N}_{2}$ three times. Then $2 \mathrm{mg}$ $10 \% \mathrm{Pd} / \mathrm{C}$ was added and the solution was degassed again with nitrogen. The reaction mixture was hydrogenated at $45 \mathrm{psi}$ at room temperature for $4 \mathrm{~h}$. The mixture was filtered over Celite and the filtrate was concentrated to afford essentially pure product as yellow oil ${ }^{23}(0.75 \mathrm{~g}, 98 \%) ;{ }^{1} \mathrm{H}$ $\operatorname{NMR}\left(\mathrm{CDCl}_{3}\right): \delta=6.50-6.42\left(\mathrm{~m}, 2 \mathrm{H}, 4-\mathrm{H}\right.$ and 6-H), $6.31(\mathrm{~m}, 1 \mathrm{H}, 2-\mathrm{H}), 3.72\left(\mathrm{~s}, 6 \mathrm{H}, \mathrm{OCH}_{3}\right), 2.63$ $\left(\mathrm{t}, J 7.1 \mathrm{~Hz}, 2 \mathrm{H}, 1^{\prime}-\mathrm{H}\right), 1.54\left(\mathrm{~m}, 2 \mathrm{H}, 2^{\prime}-\mathrm{H}\right), 1.32\left(\mathrm{~m}, 2 \mathrm{H}, 3^{\prime}-\mathrm{H}\right), 1.16\left(\mathrm{t}, J 7.9 \mathrm{~Hz}, 3 \mathrm{H}, 4^{\prime}-\mathrm{H}\right) .{ }^{13} \mathrm{C}$ NMR $\left(\mathrm{CDCl}_{3}\right): \delta=160.6$ (1-C and 3-C), 145.4 (5-C), 107.3 (4-C and 6-C), 97.5 (2-C), 56.1 $\left(\mathrm{OCH}_{3}\right), 35.9\left(1^{\prime}-\mathrm{C}\right), 33.4\left(2^{\prime}-\mathrm{C}\right), 22.3\left(3^{\prime}-\mathrm{C}\right), 13.9\left(4^{\prime}-\mathrm{C}\right)$; HPLC-MS: [A, 15\% - 100\%], $\mathrm{t}_{\mathrm{R}}=$ $5.97 \mathrm{~min},(96 \%)$; $\mathrm{MS}\left(\mathrm{ES}^{+}, \mathrm{m} / z\right) 195[\mathrm{M}+\mathrm{H}]^{+}$

5-n-Butyl-1,3-dihydroxybenzene (1c). To a solution of 5-n-butyl-1,3-dimethoxybenzene (7) $(0.63 \mathrm{~g}, 3.7 \mathrm{mmol})$ in dry $\mathrm{CH}_{2} \mathrm{Cl}_{2}$ was added dropwise boron tribromide $\left(1 \mathrm{M}\right.$ in $\mathrm{CH}_{2} \mathrm{Cl}_{2}, 4.4 \mathrm{~mL}$, $27 \mathrm{mmol}$ ) at $0{ }^{\circ} \mathrm{C}$ under $\mathrm{N}_{2}$ atmosphere. The reaction mixture was allowed to warm to room temperature and stirred for $20 \mathrm{~h}$. Then $\mathrm{MeOH}$ was carefully added at $0{ }^{\circ} \mathrm{C}$ until neutralization. The solvent was removed in vacuo and the crude mixture was purified by chromatography on silica gel (EtOAc/hexane, 1:2) to give the title compound as a brown solid (0.41 g, 65\%), mp: 80-81 ${ }^{\circ} \mathrm{C}$ (lit. $\left.{ }^{10} \mathrm{mp} 81.5-82.5{ }^{\circ} \mathrm{C}\right) ;{ }^{1} \mathrm{H}$ NMR $\left(\mathrm{CDCl}_{3}\right): \delta=6.26(\mathrm{~m}, 2 \mathrm{H}, 4-\mathrm{H}$ and 6-H), $6.20(\mathrm{~d}, J=$ $1.8 \mathrm{~Hz}, 1 \mathrm{H}, 2-\mathrm{H}), 5.83$ (s, 2H, OH), 2.50 (t, J7,5 Hz, 2H, 1'-H), 1.57-1.47 (m, 2H, 2'-H), 1.37$1.26\left(\mathrm{~m}, 2 \mathrm{H}, 3^{\prime}-\mathrm{H}\right), 0.90\left(\mathrm{t}, 3 \mathrm{H}, 4^{\prime}-\mathrm{H}\right) .{ }^{13} \mathrm{C} \mathrm{NMR}\left(\mathrm{CDCl}_{3}\right): \delta=146.5$ (5-C), 157.5 (1-C and 3-C), 
109.0 (4-C and 6-C), 100.1 (2-C), 36.5 (1'-C), 34.1 (2'- C), 23.2 (3'-C), 14.5 (4'-C); HPLC-MS: [A, 15\% - 100\%], $\mathrm{t}_{\mathrm{R}}=4.13 \mathrm{~min},(97 \%)$; MS $\left(\mathrm{ES}^{+}, \mathrm{m} / \mathrm{z}\right) 167[\mathrm{M}+\mathrm{H}]^{+}$; Anal. calcd. for $\mathrm{C}_{15} \mathrm{H}_{24} \mathrm{O}_{2}$ (166.22): C, 72.26; H, 8.49. Found: C, 72.44; H, 8.27.

General procedures for the synthesis of 5- and 7-hydroxy-2,2-dimethyl-4-chromanones.

A solution of the appropriate resorcinol 1 in methanesulfonic acid and 3,3-dimethylacrylic acid were added to a suspension of $\mathrm{P}_{2} \mathrm{O}_{5}$ in methanesulfonic acid under $\mathrm{N}_{2}$ atmosphere. The reaction mixture was heated following three different procedures: a) irradiation by microwave at $70{ }^{\circ} \mathrm{C}$ in a sealed reactor for 10 minutes; b) irradiation by microwave at $70{ }^{\circ} \mathrm{C}$ in a sealed reactor for 20 minutes; c) irradiation by microwave at $70{ }^{\circ} \mathrm{C}$ in a sealed reactor for 1 hour; d) conventional heating at $70{ }^{\circ} \mathrm{C}$ for about 12 hours. The reaction mixture was poured onto water/ice and then extracted with $\mathrm{CH}_{2} \mathrm{Cl}_{2}$. The organic layer was dried over anhydrous $\mathrm{MgSO}_{4}$. Solvent was removed under reduced pressure. The crude compounds were purified and isolated by chromatography on silica gel (hexane/EtOAc).

7-Hydroxy-2,2-dimethylchroman-4-one (3a) and 2,2,8,8-tetramethyl-2,3,8,9-tetrahydro4H,10H-pyrano[2,3-f]chromene-4,10-dione (4a). Chromanone $\mathbf{3 a}$ and compound $\mathbf{4 a}$ were prepared from resorcinol (1a) $(0.4 \mathrm{~g}, 3.60 \mathrm{mmol})$ using $\mathrm{P}_{2} \mathrm{O}_{5}(0.76 \mathrm{~g}, 5.4 \mathrm{mmol})$, methanesulfonic acid (5 mL, $77.08 \mathrm{mmol})$, and 3,3-dimethylacrylic acid (0.72 g, $7.26 \mathrm{mmol})$. Following procedures a, b, and d, 3a was isolated [b: yield $=98 \%$; d: 89\%]. Following procedure c 3a $[\mathrm{c}$ : yield $=64 \%]$ and $\mathbf{4 a}$ [c: yield $=9 \%$ ] were isolated.

7-Hydroxy-2,2-dimethylchroman-4-one (3a). White solid, mp 171-173 ${ }^{\circ} \mathrm{C}$ (lit. ${ }^{11} \mathrm{mp} 172{ }^{\circ} \mathrm{C}$ ). ${ }^{1} \mathrm{H} \mathrm{NMR}\left(\mathrm{CDCl}_{3}\right): \delta=7.95(\mathrm{~d}, J 7.1 \mathrm{~Hz}, 1 \mathrm{H}, 5-\mathrm{H}), 6.54(\mathrm{dd}, J 1.5 \mathrm{~Hz}, 1 \mathrm{H}, 8-\mathrm{H}), 6.36(\mathrm{dd}, J 7.1$ $\mathrm{Hz}, J 1.5 \mathrm{~Hz}, 1 \mathrm{H}, 6-\mathrm{H}), 2.67(\mathrm{~s}, 2 \mathrm{H}, 3-\mathrm{H}), 1.46\left(\mathrm{~s}, 6 \mathrm{H}, \mathrm{OC}\left(\mathrm{CH}_{3}\right)_{2}\right) .{ }^{13} \mathrm{C} \mathrm{NMR}\left(\mathrm{CDCl}_{3}\right): \delta=191.6$ (4-C), 163.3 (7-C), 162.1 (8a-C), 128.8 (5-C), 114.1 (4a-C), 109.8 (6-C), 103.6 (8-C), 79.5 (2-C), 48.5 (3-C), $26.6\left(\mathrm{OC}\left(\mathrm{CH}_{3}\right)_{2}\right)$; HPLC-MS: [A, 40\% - 100\%], $\mathrm{t}_{\mathrm{R}}=1.50 \mathrm{~min},(93 \%) ; \mathrm{MS}\left(\mathrm{ES}^{+}, \mathrm{m} / z\right)$ $193[\mathrm{M}+\mathrm{H}]^{+}$; Anal. calcd. for $\mathrm{C}_{11} \mathrm{H}_{12} \mathrm{O}_{3}$ (192.21): C 68.74, H 6.29, found: C 67.96, H 6.52.

2,2,8,8-Tetramethyl-2,3,8,9-tetrahydro-4H,10H-pyrano[2,3-f]chromene-4,10-dione (4a). Yellow solid, mp 160-162 ${ }^{\circ} \mathrm{C}$ (lit. $\left.{ }^{12} \mathrm{mp} 160-161{ }^{\circ} \mathrm{C}\right) ;{ }^{1} \mathrm{H}$ NMR $\left(\mathrm{CDCl}_{3}\right): \delta=7.85(\mathrm{~d}, J=7.6 \mathrm{~Hz}$, 1H, 5-H), 6.87 (d, J 7.6 Hz, 1H, 6-H), 2.66 (s, 2H, 9-H), 2.71 (s, 2H, 3-H), 1.52 (s, 6H, 11-H), $1.48(\mathrm{~s}, 6 \mathrm{H}, 12-\mathrm{H}) .{ }^{13} \mathrm{C} \mathrm{NMR}\left(\mathrm{CDCl}_{3}\right): \delta=196.6(10-\mathrm{C}), 190.3$ (4-C), $161.4(6 \mathrm{a}-\mathrm{C}), 157.1$ (10bC), 141.2 (10a-C), 134.8 (5-C), 111.1 (4a-C), 108.9 (6-C), 87.8 (8-C), 85.7 (2-C), 48.9 (9-C), 47.6 (3-C), 25.1 (11-C), 26.0 (12-C); HPLC-MS: [A, 40\% - 100\%], $\mathrm{t}_{\mathrm{R}}=3.71 \mathrm{~min},(92 \%)$; MS $\left(\mathrm{ES}^{+}, \mathrm{m} / z\right) 275[\mathrm{M}+\mathrm{H}]^{+}$; Anal. calcd. for $\mathrm{C}_{16} \mathrm{H}_{18} \mathrm{O}_{4}(274.31)$ : C 70.06, H 6.61, found: $\mathrm{C} 70.41, \mathrm{H}$ 6.58 .

7-Hydroxy-2,2,5-trimethylchroman-4-one (3b). Chromanone $3 b$ was prepared from orcinol (1b) $(0.10 \mathrm{~g}, 0.81 \mathrm{mmol})$ using $\mathrm{P}_{2} \mathrm{O}_{5}(0.17 \mathrm{~g}, 1.21 \mathrm{mmol})$, methanesulfonic acid $(3 \mathrm{~mL}, 46.25$ $\mathrm{mmol})$, and 3,3-dimethylacrylic acid $(0.12 \mathrm{~g}, 1.20 \mathrm{mmol})$ following procedures $\mathrm{a}, \mathrm{b}$ [yield = $70 \%$ ], $\mathrm{c}$ [yield $=53 \%$ ], and d [yield $=72 \%$ ]. Using procedure $\mathrm{c} \mathbf{4} \mathbf{b}^{12}$ was detected by HPLC/MS but not isolated. 3b: Dark-orange oil (lit. $\left.{ }^{13} \mathrm{mp}=190{ }^{\circ} \mathrm{C}\right) .{ }^{1} \mathrm{H} \mathrm{NMR}\left(\mathrm{CDCl}_{3}\right): \delta=6.73(\mathrm{~d}, J 1.7$ $\mathrm{Hz}, 1 \mathrm{H}, 6-\mathrm{H}), 6.39$ (d, J $1.7 \mathrm{~Hz}, 1 \mathrm{H}, 8-\mathrm{H}), 2.87$ (s, 2H, 3-H), 2.35 (s, 3H, 1'- $\left.{ }^{\prime} \mathrm{H}\right), 1.48$ (s, 6H, $\left.\mathrm{OC}\left(\mathrm{CH}_{3}\right)_{2}\right) .{ }^{13} \mathrm{C} \mathrm{NMR}\left(\mathrm{CDCl}_{3}\right): \delta=191.6$ (4-C), 167.4 (7-C), 162.6 (8a-C), 151.0 (5-C), 116.1 
(4a-C), 109.9 (6-C), 99.6 (8-C), 82.3 (2), 49.8 (3-C), $\left.27.1\left(\mathrm{OC} \mathrm{CH}_{3}\right)_{2}\right) ; 21.5$ (1'-C); HPLC-MS: [A, 10\%-100\%], $\mathrm{t}_{\mathrm{R}}=4.10 \mathrm{~min},(90 \%) ; \mathrm{MS}\left(\mathrm{ES}^{+}, \mathrm{m} / z\right) 207[\mathrm{M}+\mathrm{H}]^{+}$; Anal. calcd. for $\mathrm{C}_{12} \mathrm{H}_{14} \mathrm{O}_{3}$ (206.24): C 69.88, H 6.84, found: C 70.11, H 6.76.

7-n-Butyl-5-hydroxy-2,2-dimethylchroman-4-one (2c) and 5-n-butyl-7-hydroxy-2,2dimethylchroman-4-one (3c). Chromanones $2 \mathbf{c}$ and $3 \mathbf{c}$ were prepared from 5- $n$-butyl-1,3dihydroxybenzene (1c) $(0.06 \mathrm{~g}, 0.36 \mathrm{mmol})$ using $\mathrm{P}_{2} \mathrm{O}_{5}(0.06 \mathrm{~g}, 0.43 \mathrm{mmol})$, methanesulfonic acid $(2 \mathrm{~mL}, 30.83 \mathrm{mmol})$, and 3,3-dimethylacrylic acid $(0.054 \mathrm{~g}, 0.54 \mathrm{mmol})$ by following procedures a, b [3c: yield $=20 \% ; 2 \mathbf{c}$ : yield $=12 \%$ ], c [3c: yield $=54 \% ; 2 \mathbf{c}$ : yield $=4 \%$ ] and $\mathrm{d}$. Using procedure $\mathrm{c} \mathbf{4} \mathbf{c}$ was detected by HPLC/MS but not isolated.

7-n-Butyl-5-hydroxy-2,2-dimethylchroman-4-one (2c). Yellow oil ${ }^{24} ;{ }^{1} \mathrm{H} \mathrm{NMR}\left(\mathrm{CDCl}_{3}\right): \delta=$ 11.53 (s, 1H, OH), 6.28 (d, J 1.5 Hz, 1H, 6-H), 6.19 (d, J 1.5 Hz, 1H, 8-H), 2.65 (s, 2H, 3-H), $2.45\left(\mathrm{t}, J 7.5 \mathrm{~Hz}, 2 \mathrm{H}, 1^{\prime}-\mathrm{H}\right), 1.55\left(\mathrm{~m}, 2 \mathrm{H}, 2^{\prime}-\mathrm{H}\right), 1.40\left(\mathrm{~s}, 6 \mathrm{H}, \mathrm{OC}\left(\mathrm{CH}_{3}\right)_{2}\right), 1.25\left(\mathrm{~m}, 2 \mathrm{H}, 3^{\prime}-\mathrm{H}\right), 0.85$ $\left(\mathrm{t}, J 7.2 \mathrm{~Hz}, 3 \mathrm{H}, 4^{\prime}-\mathrm{H}\right) .{ }^{13} \mathrm{C} \mathrm{NMR}\left(\mathrm{CDCl}_{3}\right): \delta=198.0$ (4-C), 162.5 (8a-C), 160.4 (5-C), 155.5 (7C), 109.9 (6-C), 108.4 (8-C), 105.7 (4a-C), 79.0 (2-C), 49.0 (3-C), 36.9 (1'-C), 33.0 (2'-C), 22.5 $\left(3^{\prime}-\mathrm{C}\right), 27.0\left(\mathrm{OC}\left(\mathrm{CH}_{3}\right)_{2}\right), 14.0\left(4^{\prime}-\mathrm{C}\right)$; HPLC-MS: [A, 80\% - 95\%], $\mathrm{t}_{\mathrm{R}}=2.17 \mathrm{~min},(99 \%)$; $\mathrm{MS}$ $\left(\mathrm{ES}^{+}, \mathrm{m} / z\right) 249[\mathrm{M}+\mathrm{H}]^{+}$

5-n-Butyl-7-hydroxy-2,2-dimethylchroman-4-one (3c). Yellow solid ${ }^{24}, \mathrm{mp} 130-131{ }^{\circ} \mathrm{C} ;{ }^{1} \mathrm{H}$ $\operatorname{NMR}\left(\mathrm{CDCl}_{3}\right): \delta=6.27(\mathrm{~d}, J 2.5 \mathrm{~Hz}, 1 \mathrm{H}, 6-\mathrm{H}), 6.21(\mathrm{~d}, \mathrm{~J} 2.5 \mathrm{~Hz}, 1 \mathrm{H}, 8-\mathrm{H}), 5.39(\mathrm{~s}, 1 \mathrm{H}, \mathrm{OH})$, $2.90\left(\mathrm{t}, J 7.5 \mathrm{~Hz}, 2 \mathrm{H}, 1^{\prime}-\mathrm{H}\right), 2.62(\mathrm{~s}, 2 \mathrm{H}, 3-\mathrm{H}), 1.55-1.45\left(\mathrm{~m}, 4 \mathrm{H}, 2^{\prime}, 3^{\prime}-\mathrm{H}\right), 1.40(\mathrm{~s}, 6 \mathrm{H}$, $\left.\mathrm{OC}\left(\mathrm{CH}_{3}\right)_{2}\right), 0.95\left(\mathrm{t}, J 7.2 \mathrm{~Hz}, 3 \mathrm{H}, 4^{\prime}-\mathrm{H}\right) .{ }^{13} \mathrm{C} \mathrm{NMR}\left(\mathrm{CDCl}_{3}\right): \delta=192.0$ (4-C), 163.5 (8a-C), 162.5 (7-C), 150.0 (5-C), 112.7 (4a-C), 112.0 (6-C), 102.4 (8-C), 78.8 (2-C), 50.5 (3-C), 35.8 (1'-C), $34.0\left(2^{\prime}-\mathrm{C}\right), 26.9\left(\mathrm{OC}\left(\mathrm{CH}_{3}\right)_{2}\right), 23.5$ (3'-C), 14.1 (4'-C); HPLC-MS: [A, 80\% - 95\%], $\mathrm{t}_{\mathrm{R}}=0.94$ $\min ,(95 \%)$; MS $\left(\mathrm{ES}^{+}, \mathrm{m} / \mathrm{z}\right) 249[\mathrm{M}+\mathrm{H}]^{+}$; Anal. calcd. for $\mathrm{C}_{15} \mathrm{H}_{20} \mathrm{O}_{3}(248.34): \mathrm{C}$ 72.55, $\mathrm{H} \mathrm{8.12}$, found: C 72.61, H 8.22.

5-Hydroxy-2,2-dimethyl-7-n-pentylchroman-4-one (2d), 7-hydroxy-2,2-dimethyl-5-npentylchroman-4-one (3d) and 2,2,8,8-tetramethyl-5- $n$-pentyl-2,3,8,9-tetrahydro-4H,10Hpyrano[2,3-f]chromene-4,10-dione (4d). Chromanones $2 \mathrm{~d}, \mathbf{3 d}$ and compound $\mathbf{4 d}$ were prepared from olivetol (1d) (0.42 g, $2.37 \mathrm{mmol})$ using $\mathrm{P}_{2} \mathrm{O}_{5}(0.40 \mathrm{~g}, 2.80 \mathrm{mmol})$, methanesulfonic acid (5 $\mathrm{mL}, 77.08 \mathrm{mmol})$, and 3,3-dimethylacrylic acid (0.35 g, $3.50 \mathrm{mmol})$. Following procedures a and $\mathrm{d} \mathbf{2 d}$ and $\mathbf{3 d}$ were isolated [3d: yield $=50 \%(\mathrm{~d}) ; \mathbf{2 d}$ : yield $=11 \%(\mathrm{~d})]$. Following procedures $\mathrm{b}$ and c 2d, 3d and 4d were isolated [3d: yield = 37\% (b), 50\% (c); 2d: yield $=15 \%$ (b), 5\% (c); 4d: yield $=7 \%$ (b), $10 \%$ (c)].

5-Hydroxy-2,2-dimethyl-7-n-pentylchroman-4-one (2d). Orange oil (lit. ${ }^{4} \mathrm{mp} 23-27{ }^{\circ} \mathrm{C}$ ); ${ }^{1} \mathrm{H}$ NMR $\left(\mathrm{CDCl}_{3}\right): \delta=6.32(\mathrm{~d}, J 2.4 \mathrm{~Hz}, 1 \mathrm{H}, 8-\mathrm{H}), 6.26(\mathrm{~d}, J 2.4 \mathrm{~Hz}, 1 \mathrm{H}, 6-\mathrm{H}), 2.98(\mathrm{t}, J 7.1 \mathrm{~Hz}, 2 \mathrm{H}$, $\left.1^{\prime}-\mathrm{H}\right), 2.66(\mathrm{~s}, 2 \mathrm{H}, 3-\mathrm{H}), 1.48-1.53\left(\mathrm{~m}, 2 \mathrm{H}, 2^{\prime}-\mathrm{H}\right), 1.44-1.38\left(\mathrm{~m}, 2 \mathrm{H}, 3^{\prime}-\mathrm{H}\right), 1.41$ (s, 6H, $\left.\mathrm{OC}\left(\mathrm{CH}_{3}\right)_{2}\right), 1.30-1.40\left(\mathrm{~m}, 2 \mathrm{H}, 4^{\prime}-\mathrm{H}\right), 0.87\left(\mathrm{t}, J 6.9 \mathrm{~Hz}, 3 \mathrm{H}, 5^{\prime}-\mathrm{H}\right) .{ }^{13} \mathrm{C} \mathrm{NMR}\left(\mathrm{CDCl}_{3}\right): \delta=191.2$ (4-C), 161.9 (5-C), 159.7 (8a-C), 147.6 7-C), 110. 2 (8-C), 109.9 (6-C), 100.1 (4a-C), 76.4 (2-C), 48.3 (3-C), 33.3 (1'-C), 30.1 (3'-C), 28.1 (2’-C), $24.8\left(\mathrm{OC}^{\prime}\left(\mathrm{CH}_{3}\right)_{2}\right), 20.7$ (4'-C), 12.2 (5'-C); HPLC-MS: [A, 80\% - 100\%], $\mathrm{t}_{\mathrm{R}}=2.78 \mathrm{~min},(98 \%)$; MS $\left(\mathrm{ES}^{+}, \mathrm{m} / z\right) 263[\mathrm{M}+\mathrm{H}]^{+}$; Anal. calcd. for $\mathrm{C}_{16} \mathrm{H}_{22} \mathrm{O}_{3}$ (262.34): C 73.25, $\mathrm{H} 8.45$, found: C 72.98, $\mathrm{H} 8.71 \%$. 
7-Hydroxy-2,2-dimethyl-5-n-pentylchroman-4-one (3d). Pale yellow solid, mp 92-94 ${ }^{\circ} \mathrm{C}(\mathrm{mp}$ lit. $\left.{ }^{14}=91-93{ }^{\circ} \mathrm{C}\right) ;{ }^{1} \mathrm{H}$ NMR $\left(\mathrm{CDCl}_{3}\right): \delta=8.25(\mathrm{~s}, 1 \mathrm{H}, \mathrm{OH}), 6.24(\mathrm{~d}, J 2.1 \mathrm{~Hz}, 1 \mathrm{H}, 6-\mathrm{H}), 6.16(\mathrm{~d}, J$ 2,1 Hz 1H, 8-H), 2.95 (s, 2H, 3-H), 2.60 (t, J 7.1 Hz, 2H, 1'-H), 1.68 (m, 2H, 2'-H), 1.41 (s, 6H, $\left.\mathrm{OC}\left(\mathrm{CH}_{3}\right)_{2}\right), 1.33-1.26\left(\mathrm{~m}, 2 \mathrm{H}, 3^{\prime}, 4^{\prime}-\mathrm{H}\right), 0.80\left(\mathrm{t}, J 7,0 \mathrm{~Hz}, 3 \mathrm{H}, 5^{\prime}-\mathrm{H}\right) .{ }^{13} \mathrm{C} \mathrm{NMR}\left(\mathrm{CDCl}_{3}\right): \delta=$ 192.9 (4-C), 163.9 (8a-C), 162.0 (7-C), 149.9 (5-C), 112.7 (4a-C), 111.9 (6-C), 102.3 (8-C), 78.7 (2-C), 50.6 (3-C), 35.6 (2'-C), 32.4 (1'-C), 30.9 (3'-C), $29.1\left(4^{\prime}-\mathrm{C}\right), 26.9\left(\mathrm{OC}\left(\mathrm{CH}_{3}\right)_{2}\right), 14.5\left(5^{\prime}-\right.$ C); HPLC-MS: [A, 80\% - 100\%], $\mathrm{t}_{\mathrm{R}}=1.23 \mathrm{~min},(96 \%)$; $\mathrm{MS}\left(\mathrm{ES}^{+}, \mathrm{m} / \mathrm{z}\right) 263[\mathrm{M}+\mathrm{H}]^{+}$; Anal. calcd. for $\mathrm{C}_{16} \mathrm{H}_{22} \mathrm{O}_{3}$ (262.34): $\mathrm{C} 73.25, \mathrm{H} 8.45$, found: $\mathrm{C} 72.83, \mathrm{H} 8.69 \%$.

\section{2,2,8,8-Tetramethyl-5- $n$-pentyl-2,3,8,9-tetrahydro-4H,10H-pyrano[2,3-f]chromene-4,10-}

dione (4d). Yellow gummy solid; ${ }^{1} \mathrm{H} \mathrm{NMR}\left(\mathrm{CDCl}_{3}\right): \delta=6.30(\mathrm{~s}, 1 \mathrm{H}, 6-\mathrm{H}), 2.91(\mathrm{t}, J 7.1 \mathrm{~Hz}, 2 \mathrm{H}$, $\left.1^{\prime}-\mathrm{H}\right), 2.63$ (s, 2H, 9-H), 2.61 (s, 2H, 3-H), 1.64 (m, 2H, 2'-H), 1.50 (s, 6H, 11-H), 1.45 (s, 6H, 12-H), 1.31-1.20 (m, 4H, 3', 4'-H), 0.88 (t, J 8.0 Hz, 3H, 5'-H). ${ }^{13} \mathrm{C} \mathrm{NMR}\left(\mathrm{CDCl}_{3}\right): \delta=192.1$ (4C), 189.6 (10-C), 165.1 (6a-C), 163.3 (10b-C), 150.9 (5-C), 135.7 (10a-C), 117.0 (4a-C), 109.1 (6-C), 85.2 (8-C), 79.1 (2-C), 49.1 (9-C), 42.4 (3-C), 31.9 (1'-C), 30.9 (2'-C), 29.8 (3'-C), 24.3 (4'-C), 26.7 (11-C), 25.8 (12-C), 14.6 (5'-C); HPLC-MS: [A, 60\% - 100\%], $\mathrm{t}_{\mathrm{R}}=4.33 \mathrm{~min}$, (94\%); MS $\left(\mathrm{ES}^{+}, \mathrm{m} / z\right) 345[\mathrm{M}+\mathrm{H}]^{+}$; Anal. calcd. for $\mathrm{C}_{21} \mathrm{H}_{28} \mathrm{O}_{4}$ (344.44): C 73.23, H 8.19, found: C $72.86, \mathrm{H} 8.35 \%$.

7-(1,1-Dimethylheptyl)-5-hydroxy-2,2-dimethylchroman-4-one (2e). Chromanone 2e was prepared from 5-(1,1-dimethylheptyl)-1,3-dihydroxybenzene (1e) (0.10 g, $0.43 \mathrm{mmol})$ using $\mathrm{P}_{2} \mathrm{O}_{5}(0.08 \mathrm{~g}, 0.63 \mathrm{mmol})$, methanesulfonic acid $(3 \mathrm{~mL}, 46.25 \mathrm{mmol})$, and 3,3-dimethylacrylic acid $(0.06 \mathrm{~g}, 0.63 \mathrm{mmol})$ by following procedures a (yield $=60 \%), \mathrm{b}$ (yield $=52 \%$ ), c (yield = $44 \%)$ and $\mathrm{d}($ yield $=81 \%)$. Pale-yellow oil ${ }^{5} ;{ }^{1} \mathrm{H} \mathrm{NMR}\left(\mathrm{CDCl}_{3}\right): \delta=6.45(\mathrm{~d}, J=1.6 \mathrm{~Hz}, 1 \mathrm{H}, 8-\mathrm{H})$, 6.37 (d, J=1.6 Hz, 1H, 6-H), 2.71 (s, 2H, 3-H), 1.52-1.59 (m, 2H, 2'-H), 1.46 (s, 6H, OC( $\left.\left(\mathrm{CH}_{3}\right)_{2}\right)$, 1.22 (s, 6H, C( $\left.\left.\mathrm{CH}_{3}\right)_{2}\right), 1.19$ (bs, 6H, 3'-H, 4'-H, 5'-H), 1.05 (bs, 2H, 6'-H), 0.87 (m, 3H, 7'-H). ${ }^{13} \mathrm{C} \mathrm{NMR}\left(\mathrm{CDCl}_{3}\right): \delta=197.9$ (4-C), 163.0 (5-C), 161.7 (8a-C), 156.0 (7-C), 107.0 (8-C), 106.2 (6-C), 105.7 (4-C), 79.1 (2-C), 48.5 (3-C), 41.0 (2'-C), 39.2 (1'-C), 32.1, 27.1 and 23.0 (3'-C, 4'$\mathrm{C}$ and 5'-C), $30.3\left(\mathrm{C}\left(\mathrm{CH}_{3}\right)_{2}\right), 28.8\left(\mathrm{OC}\left(\mathrm{CH}_{3}\right)_{2}\right), 25.0$ (6'-C), 14.5 (7'-C); HPLC-MS: [A, 80\% $100 \%], \mathrm{t}_{\mathrm{R}}=4.9 \mathrm{~min},(97 \%)$; $\mathrm{MS}\left(\mathrm{ES}^{+}, \mathrm{m} / z\right) 318[\mathrm{M}+\mathrm{H}]^{+}$; Anal. calcd. for $\mathrm{C}_{20} \mathrm{H}_{30} \mathrm{O}_{3}$ (318.45): $\mathrm{C}$, 75.43; H, 9.50. Found: C, 75.52; H $9.64 \%$.

\section{Computational method}

The geometry of the systems has been optimized with the B3LYP/6-31G(d) computational level $^{15,16}$ within the Gaussian-09 program. ${ }^{17}$ In order to include the effect of the solvent, methanesulfonic acid, the Polarizable Continuum Method (PCM) model ${ }^{18}$ has been considered with a dielectric constant of 80 which is an intermediate value of the ones described in the literature for this solvent. ${ }^{19}$ Frequency calculations have been carried out to confirm that the structures obtained correspond to energy minima or true transition states (TS).

The NMR theoretical chemical shielding of the synthesized molecules has been calculated using the GIAO method ${ }^{20}$ at the B3LYP/6-311++G(d,p) computational level using the geometries optimized at the same level. The effect of the solvent used in the experimental NMR 
measurements $\left(\mathrm{CDCl}_{3}\right)$ has been simulated using the PCM model of this solvent. The calculated absolute chemical shieldings have been transformed into chemical shifts using empirical relationships previously described. ${ }^{21,22}$

\section{Acknowledgements}

This work was supported by the Spanish Ministry of Economy and Competitivity: Grants SAF 2009-12422, CTQ 2012-35513-C02-02, SAF 2012-40075, Red de Trastornos Adictivos (RETICS RD06/001/0000 and RD06/001/0014), from the Madrid Government (CANNAB-CM: S2010/BMD-2308). P.M. is recipient of JAE-Pre (ref. JAEPre-2010-01119) postgraduate fellowships from CSIC. LMA thanks the MICINN for a PhD grant ( ${ }^{\circ}$ BES-2010-031225). Gratitude is also due to the CTI (C.S.I.C.) for an allocation of computer time.

\section{References}

1. Saengchantara, S. T.; Wallace, T. W. Nat. Prod. Rep. 1986, 3, 465. http://dx.doi.org/10.1039/np9860300465

2. Friedrichfiechtl, J.; Spiteller, G. Tetrahedron 1975, 31, 479. http://dx.doi.org/10.1016/0040-4020(75)85016-2

3. Ahmed, S. A.; Ross, S. A.; Slade, D.; Radwan, M. M.; Khan, I. A.; Elsohly, M. A. Tetrahedron Lett. 2008, 49, 6050. http://dx.doi.org/10.1016/j.tetlet.2008.07.178

4. Fahrenholtz, K. E.; Lurie, M.; Kierstead, R. W. J. Am. Chem. Soc. 1967, 89, 5934. http://dx.doi.org/10.1021/ja00999a034

5. Cumella, J.; Hernandez-Folgado, L.; Giron, R.; Sanchez, E.; Morales, P.; Hurst, D. P.; Gomez-Canas, M.; Gomez-Ruiz, M.; Pinto, D.; Goya, P.; Reggio, P. H.; Martin, M. I.; Fernandez-Ruiz, J.; Silva, A. M. S.; Jagerovic, N. ChemMedChem 2012, 7, 452. http://dx.doi.org/10.1002/cmdc.201100568

6. Timar, T.; Levai, A.; Eszenyi, T.; Sebok, P. J. Heterocycl. Chem. 2000, 37, 1389.

7. Arnoldi, A. Synthesis 1984, 856.

8. Camps, F.; Coll, J.; Messeguer, A.; Pericas, M. A.; Ricart, S.; Bowers, W. S.; Soderlund, D. M. Synthesis 1980, 725.

9. Sonogashira, K. J. Organomet. Chem. 2002, 653, 46. http://dx.doi.org/10.1016/s0022-328x(02)01158-0

10. Suter, C. M.; Weston, A. W. J. Am. Chem. Soc. 1939, 61, 232. http://dx.doi.org/10.1021/ja01871a004

11. Offe, H. A. Chem. Ber. 1947, 80, 449. http://dx.doi.org/10.1002/cber.19470800514 
12. Vijayalakshmi, C. S.; Subramanian, M.; Prasad, K. J. R. Indian J. Chem. Sect B-Org. Chem. Incl. Med. Chem. 1990, 29, 661.

13. Ramana, M. M. V.; Kudav, N. A. Indian J. Chem. Sect B-Org. Chem. Incl. Med. Chem. 1988, 27, 339.

14. Press, J. B.; Birnberg, G. H. J. Heterocycl. Chem. 1985, 22, 561.

15. Becke, A. D. J. Chem. Phys. 1993, 98, 5648.

http://dx.doi.org/10.1063/1.464913

16. Hariharan, P.C.; Pople, J. A. Theor. Chim. Acta 1973, 28, 213. http://dx.doi.org/10.1007/bf00533485

17. Frisch, M. J.; Trucks, G. W.; Schlegel, H. B.; Scuseria, G. E.; Robb, M. A.; Cheeseman, J. R.; Scalmani, G.; Barone, V.; Mennucci, B.; Petersson, G. A.; Nakatsuji, H.; Caricato, M.; Li, X.; Hratchian, H. P.; Izmaylov, A. F.; Bloino, J.; Zheng, G.; Sonnenberg, J. L.; Hada, M.; Ehara, M.; Toyota, K.; Fukuda, R.; Hasegawa, J.; Ishida, M.; Nakajima, T.; Honda, Y.; Kitao, O.; Nakai, H.; Vreven, T.; Montgomery, J., J. A.; Peralta, J. E.; Ogliaro, F.; Bearpark, M.; Heyd, J. J.; Brothers, E.; Kudin, K. N.; Staroverov, V. N.; Kobayashi, R.; Normand, J.; Raghavachari, K.; Rendell, A.; Burant, J. C.; Iyengar, S. S.; Tomasi, J.; Cossi, M.; Rega, N.; Millam, N. J.; Klene, M.; Knox, J. E.; Cross, J. B.; Bakken, V.; Adamo, C.; Jaramillo, J.; Gomperts, R.; Stratmann, R. E.; Yazyev, O.; Austin, A. J.; Cammi, R.; Pomelli, C.; Ochterski, J. W.; Martin, R. L.; Morokuma, K.; Zakrzewski, V. G.; Voth, G. A.; Salvador, P.; Dannenberg, J. J.; Dapprich, S.; Daniels, A. D.; Farkas, Ö.; Foresman, J. B.; Ortiz, J. V.; Cioslowski, J.; Fox, D. J.; Gaussian, Inc.: Wallingford CT, 2009.

18. Tomasi, J.; Persico, M. Chem. Rev. 1994, 94, 2027. http://dx.doi.org/10.1021/cr00031a013

19. Roitman, D. B.; McAlister, J.; McAdon, M.; Wessling, R. A. J. Polym. Sci. Part B,-Polym. Phys. 1994, 32, 1157.

http://dx.doi.org/10.1002/polb.1994.090320703

20. London, F. J. Phys. Paris 1937, 8, 397. http://dx.doi.org/10.1051/jphysrad:01937008010039700

21. Silva, A. M. S.; Sousa, R. M. S.; Jimeno, M. L.; Blanco, F.; Alkorta, I.; Elguero, J. Magn. Reson. 2008, 46, 859. http://dx.doi.org/10.1002/mrc.2272

22. Blanco, F.; Alkorta, I.; Elguero, J. Magn. Reson. 2007, 45, 797. http://dx.doi.org/10.1007/s11224-007-9245-z

23. Novak, J.; Salemink, C. A. Synthesis 1983, 7, 597.

24. Arnoldi, A.; Bonsignori, A.; Melloni, P.; Merlini, L.; Quadri, M. L.; Rossi, A. C.; Valsecchi, M. J. Med. Chem. 1990, 33, 2865.

http://dx.doi.org/10.1021/jm00172a030 